\title{
Seladin-1 expression is regulated by promoter methylation in adrenal cancer
}

\author{
Lisa Simi , Francesca Malentacchi , Paola Luciani², Stefania Gelmini', Cristiana Deledda², Rosaria Arvia1, \\ Massimo Mannelli2, Alessandro Peri² and Claudio Orlando*1
}

\begin{abstract}
Background: Seladin-1 overexpression exerts a protective mechanism against apoptosis. Seladin-1 mRNA is variably expressed in normal human tissues. Adrenal glands show the highest levels of seladin-1 expression, which are significantly reduced in adrenal carcinomas (ACC). Since up to now seladin-1 mutations were not described, we investigated whether promoter methylation could account for the down-regulation of seladin-1 expression in ACC.
\end{abstract}

Methods: A methylation sensitive site was identified in the seladin-1 gene. We treated DNA extracted from two ACC cell lines (H295R and SW13) with the demethylating agent 5-Aza-2-deoxycytidine (5-Aza). Furthermore, to evaluate the presence of an epigenetic regulation also 'in vivo', seladin-1 methylation and its mRNA expression were measured in 9 ACC and in 5 normal adrenal glands.

Results: The treatment of cell lines with 5-Aza induced a significant increase of seladin-1 mRNA expression in H295R (fold increase, F.I. $=1.8 ; p=0.02$ ) and SW13 (F.I. $=2.9 ; p=0.03$ ). In ACC, methylation density of seladin-1 promoter was higher $(2682 \pm 686)$ than in normal adrenal glands ( $362 \pm 97 ; p=0.02)$. Seladin-1 mRNA expression in ACC (1452 \pm 196$)$ was significantly lower than in normal adrenal glands (3614 $\pm 949 ; p=0.01)$.

Conclusion: On this basis, methylation could be involved in the altered pattern of seladin-1 gene expression in ACC.

\section{Background}

Seladin-1 (Selective Alzheimer disease indicator 1, seladin-1) gene (chromosome 1p33-31.1), firstly identified in neuronal cells [1], codes for the cholesterol synthesizing enzyme (3-beta-hydroxysterol delta-24-reductase, DHCR24) and show high homology to the Diminuto like protein, a cell elongation factor described in Arabidopsis thaliana [2]. The expression of seladin-1 mRNA and protein is down-regulated in brain regions affected by Alzheimer's disease [1,3].

The involvement of seladin-1 in human cancers was recently investigated. Seladin-1 mRNA expression is activated in response to Ras expression, showing features of a potential tumor suppressor involved in the oncogenic signalling mediated by Ras/p53 [4]. The ablation of this gene in the presence of oncogenic and oxidative stress results in cell transformation. With regard to the enzymatic activity of seladin- 1 involving cholesterol synthesis, it is

* Correspondence: c.orlando@dfc.unifi.it

${ }^{1}$ Clinical Biochemistry, Department of Clinical Physiopathology, University of Florence, viale Pieraccini 6, Florence, 50139 Italy

Full list of author information is available at the end of the article known that some cancers show increased cholesterol content compared to normal tissues. The latter finding was accompanied by an enhanced anti-oxidant activity and consequent resistance to oxidative stress, thus conferring selective growth advantage to tumor cells $[5,6]$. The inhibition of caspase 3 and a key role in cholesterol synthesis represent the two main biological functions of seladin-1. In the latter case, it is still unclear whether the effects of seladin-1 are an indirect consequence of the modulation of intracellular cholesterol, which has well documented protective effects in vitro and in vivo [7-11].

Seladin-1 was investigated in prostate [12-14], ovary [15], bladder [16] and breast cancer [17], in melanoma [18] and pituitary adenomas [19].

Adrenal gland is the human tissue with the highest levels of expression of seladin-1 [1] whereas mRNA levels are markedly reduced in adrenal carcinomas, reaching the lowest levels in advanced disease (stages III-IV) [20]. Nevertheless, the demonstrated antiapoptotic role of seladin-1 [4,21] mainly due to its $\mathrm{H}_{2} \mathrm{O}_{2}$ scavenging activity [22] may give rise to difficulties in the meaning of sela- 
din-1 downregulation in adrenal cancer. However, increased proliferation rate in tumoral cells may lead to increased apoptotic death [20]. It has been also reported that seladin-1 mRNA expression in cultured cells is modulated by ACTH $[20,23]$, suggesting that its down-regulation in adrenal cancer may be due to a reduced expression of its receptor, as a marker of loss of differentiation.

In the hypothesis that epigenetic modifications may influence differential expression of seladin-1 in adrenal cancer we analyzed whether methylation could be regarded as a mechanism of seladin-1 regulation in human adrenal cancer cell lines and tissues.

\section{Methods}

\section{Cell cultures and treatment}

Two adrenal gland-derived cell lines, H295R and SW13, were used for this study. Cell lines were maintained at $37^{\circ} \mathrm{C}$ in a $95 \%$ air and $5 \% \mathrm{CO}_{2}$ fully humidified environment in a culture medium consisting of a $1: 1(\mathrm{vol} / \mathrm{vol})$ mixture of DMEM/F-12 with 10\% FBS, 2 mm glutamine, $100 \mathrm{U} / \mathrm{ml}$ penicillin, and $100 \mu \mathrm{g} / \mathrm{ml}$ streptomycin. For H295R, medium was enriched with a mixture of insulin/ transferrin/selenium. Cells were plated in duplicate and treated with $5 \mu \mathrm{M}$ of 5-Aza-2-deoxycytidine (5-Aza) for 1,3 and 6 days. Three separate experiments were performed in the same experimental conditions and results were calculated as the mean of such replicates. RNA extraction was performed with Rneasy MiniKit Qiagen columns, while DNA was obtained by using QIAamp DNA Mini Kit (Qiagen, Milan, Italy).

\section{Patients}

A total of 14 samples, collected in the Surgical Department of the Azienda Ospedaliera Careggi, Florence, with the approval of the local Ethics Committee, included 9 adrenal carcinomas and 5 normal adrenal from patients undergoing nephrectomy for renal cancer. Informed consent was obtained from each patient. All samples were accurately examined by an expert pathologist to prevent contaminations from contiguous tissues. Samples were immediately snap frozen in liquid nitrogen until acid nucleic extraction. For RNA extraction, tissues were disrupted by homogenisation in $600 \mu \mathrm{l}$ of guanidine isothiocyanate containing lysis buffer and then processed with Rneasy MiniKit Qiagen columns. Genomic DNA was extracted from neoplastic tissues using DNeasy Tissue Kit (Qiagen Milan, Italy).

\section{Reverse transcription and quantitative real-time PCR}

Total RNA (200 ng) was reverse transcribed in a $40 \mu \mathrm{l}$ reaction mixture containing TaqMan RT buffer $1 \times, 5.5$ $\mathrm{mM} \mathrm{MgCl} 2,500 \mu \mathrm{M}$ each dNTPs, $2.5 \mu \mathrm{M}$ random hexamers, $0.4 \mathrm{U} / \mu \mathrm{l}$ RNase inhibitors and $1.25 \mathrm{U} / \mu \mathrm{l}$ MultiScribe reverse transcriptase. The profile of the one step reverse transcription reaction was $10 \mathrm{~min}$ at $25^{\circ} \mathrm{C}, 30 \mathrm{~min}$ at $48^{\circ} \mathrm{C}$ and $2 \mathrm{~min}$ at $95^{\circ} \mathrm{C}$. The PCR reaction was performed with $25 \mathrm{ng}$ cDNA, in a reaction mix containing $300 \mathrm{nM}$ of forward primer, $900 \mathrm{nM}$ of reverse primer, 12.5 $\mu \mathrm{l}$ Universal Master Mix and $200 \mathrm{nM}$ of each fluorescent probe. Plates were treated $2 \mathrm{~min}$ at $50^{\circ} \mathrm{C}, 10 \mathrm{~min}$ at $95^{\circ} \mathrm{C}$ and then submitted to 40 cycles of amplification at $95^{\circ} \mathrm{C}$ for $15 \mathrm{~s}, 60^{\circ} \mathrm{C}$ for $60 \mathrm{~s}$ in the ABI Prism 7700 Sequence Detector PE Applied Biosystems (Foster City, CA, USA). Seladin-1 mRNA expression was evaluated with relative quantitative RT-PCR using primers and probe as previously reported [20]. The integrity of total RNA was verified in all samples with Agilent 2100 bioanalyzer and as reference gene the evaluation of GAPDH mRNA expression was performed by using the Pre-Developed TaqMan Assay Reagent, GAPDH endogenous control kit from Applied Biosystems.

\section{Methylation specific PCR}

Methyl Primer Express Software v1.0 (Applied Biosystems, Foster City, CA, USA) was used to evaluate methylation-sensitive sites in seladin-1 sequence from $-4384 \mathrm{bp}$ and $+1826 \mathrm{bp}$. The region from $-4384 \mathrm{bp}$ to -1150 did not reveal any $\mathrm{CpG}$ island. In the remaining sequence, we identified a large 1786 bp long CpG island from - 868 bp o +918 bp. We analyzed two separate sequences in this region by MSP: the first, from -404 bp to $-136 \mathrm{bp}$ did not evidence methylation sensitive site (data not shown). In the second region, partially comprising exon 1 and the transcription starting site (Figure 1; see also Ref [4] for more sequence details) we selected a primer set for methylated form with the following sequences: F2 meth 5'CGGGTTGTGGGTTATAGGC-3', localised at -97 and R2 meth 5'-ACGAACACCCAACGCTAATAAAT-3' at +81 nucleotide from the same site (amplicon length 202 $\mathrm{bp})$. The unmethylated form of the same sequence was amplified using the primers: F2unmeth 5'-TTGTGGGTTATAGGTGTAGAGT-3' at -93 nucleotide from translation start site and R2unmeth 5'-CCAAACACACAC ATAATAATAAA-3' at +141 (amplicon length of $258 \mathrm{bp}$ ).

DNA from cell lines and tissue samples (500 ng) was submitted to bisulphite modification using EpiTect Bisulfite Kit (Qiagen, Milan, Italy) following manufacturer's protocol. For each treatment, CpG Genome Universal Methylated and Unmethylated DNA (Chemicon International Inc, USA) were used as positive and negative controls to confirm specificity of methylation specific PCR (MSP). After bisulphite treatment, DNA was immediately submitted to PCR analysis.

MSP was performed submitting modified DNA to $94^{\circ} \mathrm{C}$ for $5 \mathrm{~min}$ and 50 cycles at the sequent conditions: $94^{\circ} \mathrm{C}$ for $30 \mathrm{sec}, 58^{\circ} \mathrm{C}$ for $30 \mathrm{sec}, 72^{\circ} \mathrm{C}$ for $30 \mathrm{sec}$ and a final hold to $72^{\circ} \mathrm{C}$ for $10 \mathrm{~min}$. PCR product were then resolved in a $2 \%$ agarose gel. 


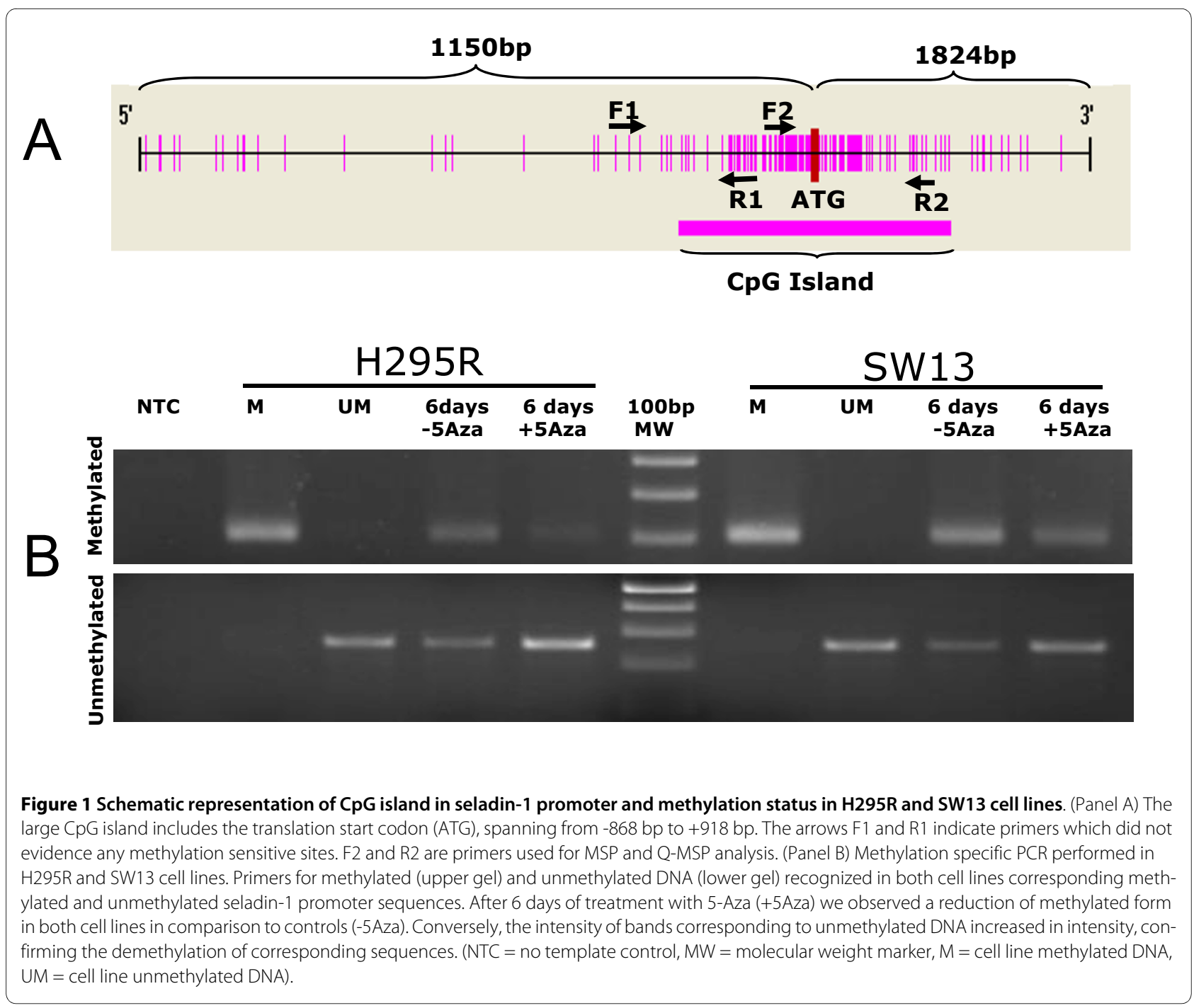

\section{Quantitative methylation specific PCR for methylation analysis}

Q-MSP was performed to confirm qualitative results using a real time RT-PCR assay. Quantitative analysis was performed on RotorGene 3000 (Corbett Research, Australia) in a final volume of $10 \mu \mathrm{l}$ with Quantitect Probe PCR Master Mix 2× (Qiagen, Milan, Italy), primers 600 $\mathrm{nmol} / \mathrm{l}$ and probe $200 \mathrm{nmol} / \mathrm{l}$ and $1 \mu \mathrm{l}$ of modified DNA. Specificity of the assay was achieved using the same primers for the methylated DNA together with an internal probe selected by PrimerExpress software (Applied Biosystems, Foster City, CA, USA) with sequence: $5^{\prime}$-TTG GCG GTA GTG ATA G-3', localised at -56 nucleotide from transcription start site and labelled with FAM. PCR conditions were: $95^{\circ} \mathrm{C}$ for $15 \mathrm{~min}, 55$ cycles at $95^{\circ} \mathrm{C}$ for 15 sec and $60^{\circ} \mathrm{C}$ for $60 \mathrm{sec}$. In all samples $\beta$-Actin DNA was analysed after bisulfite treatment using primers and probe previously described [24] to perform relative quantification. As for mRNA analysis, changes in DNA methy- lation pattern were evaluated considering the treated/ untreated ratio. The same protocol was used to perform seladin-1 quantification in normal adrenal gland samples and carcinomas.

\section{Pyrosequencing analysis}

Analysis of sequences after bisulfite treatment was performed by Pyrosequencing ${ }^{\text {TM }}$ (PyroMark ID System, Biotage, Sweden) technology. Primers selected to perform amplification were designed using PyroQ-CpG ${ }^{\mathrm{rm}}$ Software (Biotage, Sweden) and were: FW 5'-GTT TGA AGG GGT TGG AGT-3' and RV 5'-CTC ACC TAC TTC TAA ATA TCC C-3'. Amplification has been performed using one hundred nanograms of total DNA in a PCR reaction mix in $50 \mu \mathrm{l}$ final volume. Samples were denatured for $9 \mathrm{~min}$ at $94^{\circ} \mathrm{C}$ followed by 40 cycles of amplification at $94^{\circ} \mathrm{C}$ for $1 \mathrm{~min}, 55^{\circ} \mathrm{C}$ for $1 \mathrm{~min}$ and then $72^{\circ} \mathrm{C}$ for $90 \mathrm{sec}$, in a Gene Amp 9700 Thermal Cycler (Applied Biosystems, Milan, Italy). Thirty $\mu$ l of PCR product were 
used for immobilization by streptavidin sepharose beads (Streptavidin Sepharose ${ }^{\mathrm{TM}}$ High Performance, GE Healthcare Bio-Science AB, Sweden) and then incubation at $95^{\circ} \mathrm{C}$ for 5 minutes of single-stranded DNA with the sequencing primer, a biotynilated reverse primer with the same sequence used in PCR, has been performed.

\section{Statistical analysis}

Statistical analysis was carried out using the SPSS software package (SPSS INC, Chicago, IL). The Wilcoxon Rank-Sum test for paired samples was used to test differences in control cells versus cells treated with demethylating 5-Aza, while Kolmogorov-Smirnov test data was used to evaluate differences between adrenal carcinomas and normal adrenal glands. Differences with $\mathrm{p}<0.05$ were considered statistically significant.

\section{Results}

Methylation specific PCR (MSP) of methylation-sensitive promoter region

DNA extracted from H295R and SW13 cell lines was submitted to MSP with primers targeting methylated and unmethylated alleles, alternatively. As reported in Figure 1 , in both cases amplification generated amplicons with the expected size, suggesting that methylation of seladin1 promoter is in hemi-methylated status in both cell lines. When cell lines were submitted to 5-Aza treatment, MSP revealed a reduction of the intensity of the band corresponding to methylated DNA in comparison to untreated cell lines, which was paralleled by an increase of amplification products when primers for unmethylated DNA were used (Figure 1, Panel B).

\section{Quantitative methylation specific PCR (qMSP) of seladin-1 promoter methylation in vitro}

We assessed the methylation and expression patterns of seladin-1 in adrenal cell lines submitted to the same protocol of treatment with 5-Aza. Results obtained from qMSP in DNA extracted from treated cell lines (Figure 2, panel A) indicated that the levels of DNA methylation progressively decreased in both cell lines under treatment, with the maximal effect of 5-Aza on DNA methylation observed after six days. Apparently the effect was more evident on SW13, probably due to the higher proliferation rate of this line in comparison to H295R cells. The same treatment induced a progressive up-regulation of seladin-1 mRNA expression. Once again the positive effect appeared more evident for SW13 cells, whereas the induction on seladin-1 expression in H295R cells was less marked (Figure 2, panel B).

\section{Relationship between seladin mRNA expression and methylation pattern in adrenal tissues}

To test whether seladin-1 could be epigenetically regulated also 'in vivo', promoter methylation and its mRNA

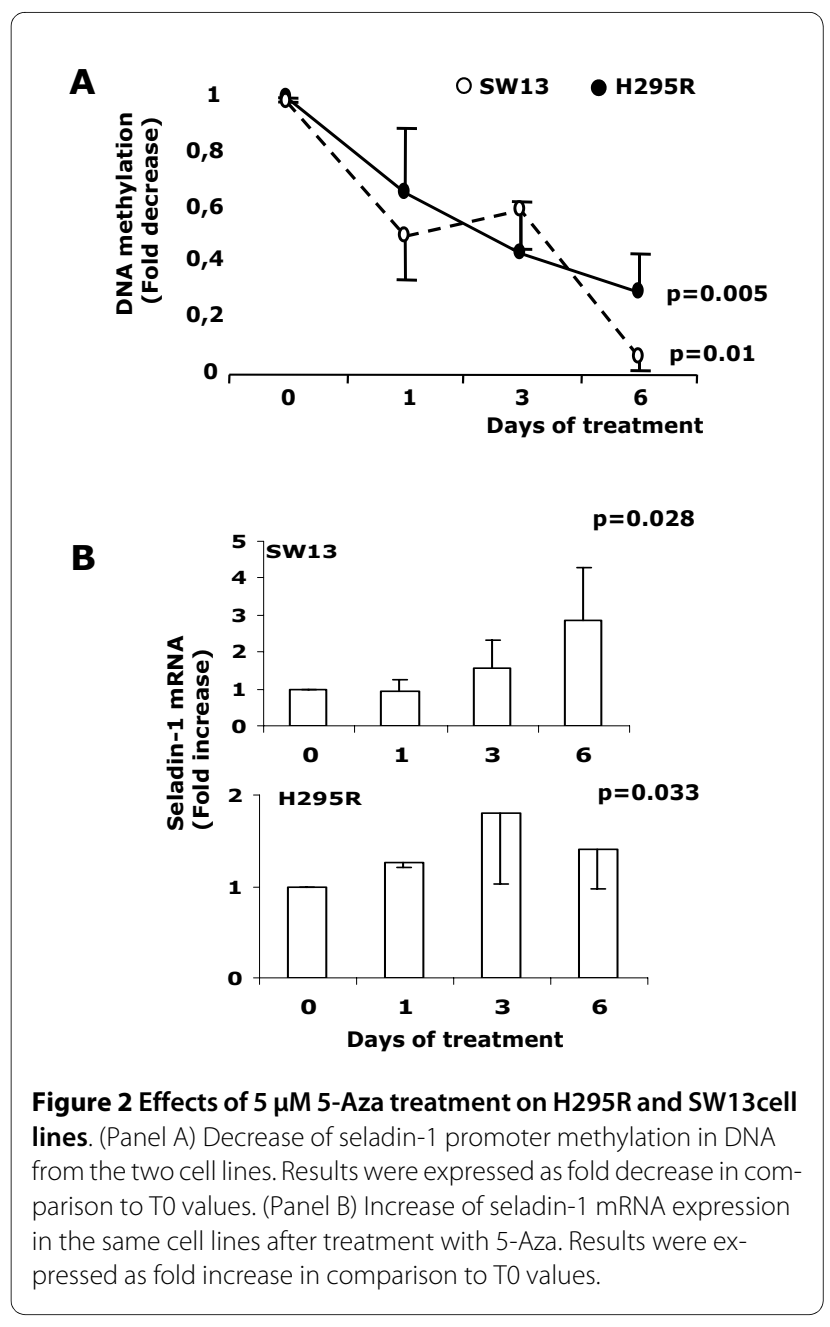

expression were measured in 9 adrenal carcinomas and in 5 normal adrenal glands. For seladin-1 mRNA, our results confirmed those previously reported [20]: in adrenal carcinomas seladin-1 mRNA $(1434 \pm 192)$ was significantly lower than in normal adrenal glands $(3433 \pm 826$; $\mathrm{p}$ $=0.01$ ) (Figure 3). Conversely, DNA methylation evidenced a statistically significant $(\mathrm{p}=0.02)$ increase in carcinoma samples $(2633 \pm 707)$ compared to normal tissues $(362 \pm 97)$.

The presence of differential patterns of methylation between DNA from adrenal carcinomas and normal adrenal glands was confirmed with pyrosequencing. An example of respective pyrograms is reported in Figure 4.

\section{Discussion}

Epigenetic events, such as DNA methylation, are crucial in establishing the correct pattern of gene expression. Disruption of this program leads to an aberrant mRNA transcription and potential loss of anti-cancer checkpoints.

The role of seladin-1 in cancer is still unclear, probably due to the multiple roles of this gene in regulating cell 


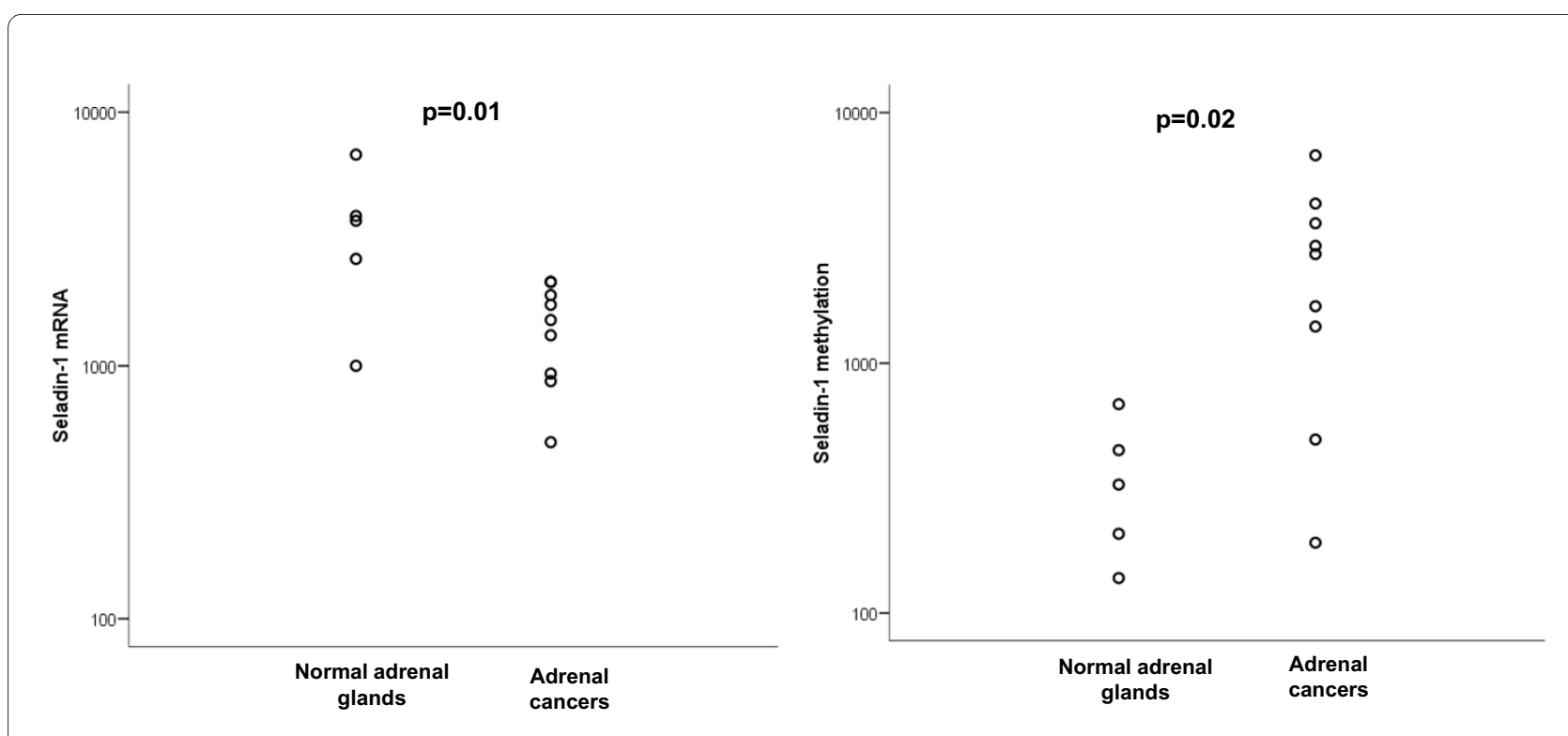

Figure 3 Seladin-1 mRNA expression (panel A) and DNA methylation (panel B) in normal adrenal glands $(n=5)$ and carcinomas $(n=9)$.

functions. However, a thorough analysis of seladin-1 role in oncogenesis and oxidative stress indicated that its expression is involved in the regulation of Ras-induced transformation and senescence in human and rodent cells [4]. Apparently, seladin-1 exerts its protective effects against oxidative stress following two independent ways. Seladin-1 is up-regulated as a response to acute oxidative stress, with a cholesterol-dependent mechanism, but is down-regulated upon chronic exposure to oxidative stress. However, also the reduction of seladin-1 expression appears involved in a prosurvival strategy due to its interaction with p53 status and function, as recently demonstrated [25]. The initial consideration that adrenal glands show very high mRNA expression levels of seladin-1 [1] and that adrenal carcinomas show a significant reduction of seladin-1 mRNA [20], has prompted a deeper analysis of this gene expression in adrenal cancer. On this basis, the definition of the regulation of seladin-1 expression seems to be crucial for the comprehension of the mechanisms underlying its downregulation in tumoral tissues.

In the present study we demonstrated for the first time the presence of a functionally active CpG island in the regulatory sequence of Seladin-1 gene. Qualitative and quantitative methylation specific PCR clearly indicated that in the adrenal cancer cell lines H295R and SW13 the $\mathrm{CpG}$ island is densely methylated and that the treatment with the 5-Aza was able to decrease DNA methylation. In the same experiments we demonstrated that the expression of seladin-1 mRNA could be directly related to the altered pattern of promoter methylation since exposure of adrenal cell lines to 5-Aza was associated to a signifi- cant induction of Seladin-1 mRNA expression in SW13 and H295R lines, even if the effects of 5-AZA on H295R methylation is apparently less evident than in SW13. This difference could refer to the different proliferation rate of the two cell lines. The higher proliferative rate of SW13 can explain the major effect of 5-AZA in reducing DNA methylation, since the incorporation of citosine analogue is much more elevated in cells with a shorter duplication time. After 6 days of treatment, methylation in SW13 is close to $0 \%$ and the effect of Seladin-1 mRNA expression is maximal. Conversely, H295R tend to proliferate more slowly and after 6 days $30 \%$ of their DNA is still methylated and the gain of mRNA expression, even if significantly increased, is less intense than in SW13.

In addition, we experienced also a different effect of the demethylating agent on the respective proliferation rate. 5 -Aza treatment induced a reduction of cell growth in H295R that reaches a 50\% inhibition after a 6-days treatment, as previously reported $[26,27]$, whereas the reduction of cell line growth in SW13 was only $15 \%$ in comparison to controls. Therefore, the discrepancy of the effects in the two cell lines is probably connected to their ability to grow in normal cultural conditions and under 5AZA treatment.

After these preliminary indications obtained 'in vitro', we tried to confirm the presence of an epigenetic control of seladin-1 expression also in 'ex vivo' samples. Real time analysis performed on the same promoter region in DNA of adrenal carcinomas, adenomas and normal glands showed an inverse relationship between methylation of seladin-1 and its expression. In particular hypermethylation was associated to reduced seladin-1 expression levels 


\section{Page 6 of 8}
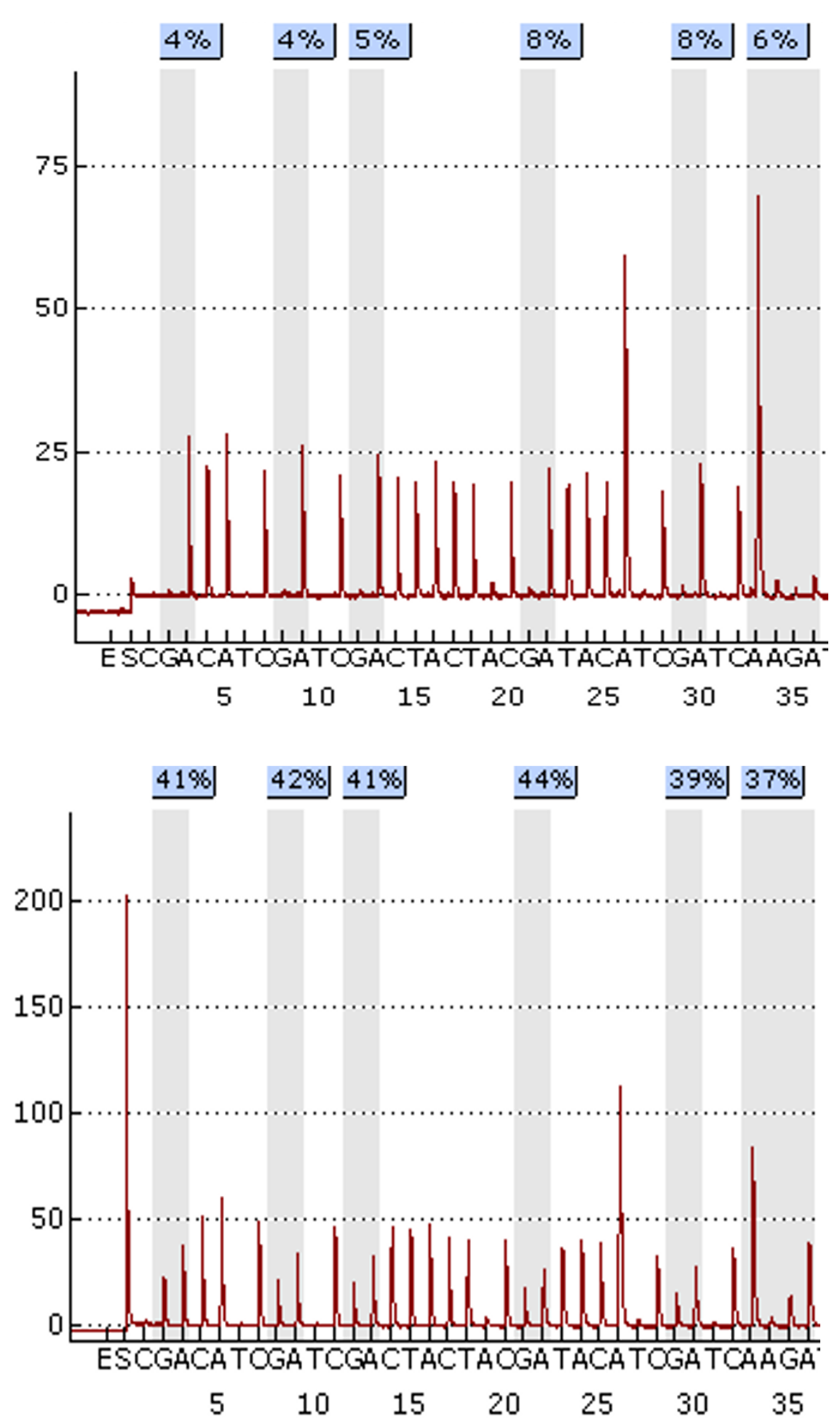

Figure 4 Examples of two pyrograms showing a different pattern of methylation in one normal adrenal gland (upper panel) and one adrenal carcinoma (lower panel). 
in adrenal cancer compared to normal adrenal gland and adenomas. No significant difference between adenomas and normal adrenal glands was evidenced. Thus, at least in adrenal carcinomas, hypermethylation could account for the reduction of mRNA expression [20].

To our knowledge, this is the first evidence that the pattern of expression of seladin-1 may be regulated by a differential methylation status of the promoter region of this gene, even if the transcription activation after 5-Aza is not a final confirmation of a direct epigenetic regulation on the gene itself. In fact an indirect effect resulting from the demethylation of other genes regulating seladin-1 expression cannot be excluded. Additional studies should be performed in order to determine whether the degree of methylation may account for the different levels of expression between normal and pathologic tissues detected in other human organs

\section{Conclusion}

According to our results, methylation could be involved in the altered pattern of seladin-1 gene expression in ACC.

\section{Competing interests}

The authors declare that they have no competing interests.

\section{Authors' contributions}

LS carried out the molecular genetics study, the statistical analysis and drafted the manuscript. FM carried out cell line experiments and participated in results analysis. PL and CD carried out mRNA expression experiments. SG participated in the molecular genetics study and mRNA expression data analysis. RA participated in the molecular genetics study. MM and AP participated in the study design, results analysis and interpretations. CO conceived of the study, drafted the manuscript and participated in its design, coordination and results interpretations. All Authors read and approved the final version of the manuscript.

\section{Acknowledgements}

The study was supported by a grant of Italian Ministry for University and Research (PRIN-2006)

\section{Author Details}

'Clinical Biochemistry, Department of Clinical Physiopathology, University of Florence, viale Pieraccini 6, Florence, 50139 Italy and ${ }^{2}$ Endocrinology Units, Department of Clinical Physiopathology, University of Florence, viale Pieraccini 6, Florence, 50139 Italy

Received: 5 August 2009 Accepted: 13 May 2010

Published: 13 May 2010

\section{References}

1. Greeve I, Hermans-Borgmeyer I, Brellinger C, Kasper D, Gomez-Isla T, Behl C, Levkau BM, Nitsch R: The human DIMINUTO/DWARF1 homolog seladin-1 confers resistance to Alzheimer's disease-associated neurodegeneration and oxidative stress. Journal of Neurosciences 2000, 20:7345-7352.

2. Takahashi T, Gasch A, Nishizawa N, Chua NH: The DIMINUTO gene of Arabidopsis is involved in regulating cell elongation. Genes \& Development 1995, 9:97-107.

3. Iivonen S, Hiltunen M, Alafuzoff I, Mannermaa A, Kerokoski P, Puoliväli J, Salminen A, Helisalmi S, Soininen H: Seladin-1 transcription is linked to neuronal degeneration in Alzheimer's disease. Neuroscience 2002, 113:301-310.
4. Wu C, Miloslavskaya I, Demontis S, Maestro R, Galaktionov K: Regulation of cellular response to oncogenic and oxidative stress by Seladin-1. Nature 2004, 432:640-645.

5. Freeman MR, Solomon KR: Cholesterol and prostate cancer. Journal of cellular Biochemistry 2004, 91:54-69.

6. Kolanjiappan K, Ramachandran CR, Manoharan S: Biochemical changes in tumor tissues of oral cancer patients. Clinical Biochemistry 2003, 36:61-65.

7. Fassbender K, Simons M, Bergmann C, Stroick M, Lutjohann D, Keller P, Runz H, Kuhl S, Bertsch T, von Bergmann K, Hennerici M, Beyreuther K, Hartmann T: Simvastatin strongly reduces levels of Alzheimer's disease beta -amyloid peptides Abeta 42 and Abeta 40 in vitro and in vivo. Proceeding of the National Academy of Sciences of the United States of America 2001, 98:5856-5861.

8. Arispe N, Doh M: 2002 Plasma membrane cholesterol controls the cytotoxicity of Alzheimer's disease AbetaP (1-40.) and (1-42.) peptides. FASEB Journal 2001, 16:1526-1536.

9. Crameri A, Biondi E, Kuehnle K, Lutjohann D, Thelen KM, Perga S, Dotti CG, Nitsch RM, Ledesma MD, Mohajeri MH: The role of seladin-1/DHCR24 in cholesterol biosynthesis, APP processing and Abeta generation in vivo. EMBO Journal 2006, 25:432-443.

10. Hartmann T, Kuchenbecker J, Grimm MO: Alzheimer's disease: the lipid connection. Journal of Neurochemistry 2007, 103:159-170.

11. Xiong H, Callaghan D, Jones A, Walker DG, Lue LF, Beach TG, Sue LI, Woulfe J, Xu H, Stanimirovic DB, Zhang W: Cholesterol retention in Alzheimer's brain is responsible for high beta- and gamma-secretase activities and Abeta production. Neurobiology of Disease 2008, 29:422-437.

12. Nelson PS: Identifying immunotherapeutic targets for prostate carcinoma through the analysis of gene expression profiles. Annals of the New York Academy of Sciences 2002, 975:232-246.

13. Zhang H, Dong Y, Zhao H, Brooks JD, Hawthorn L, Nowak N, Marshall JR, Gao AC, Ip C: Microarray data mining for potential selenium targets in chemoprevention of prostate cancer. Cancer Genomics and Proteomics 2005, 2:97-114

14. Hendriksen PJ, Dits NF, Kokame K, Veldhoven A, van Weerden WM, Bangma CH, Trapman J, Jenster G: Evolution of the androgen receptor pathway during progression of prostate cancer. Cancer Research 2006 66:5012-5020.

15. Fuller PJ, Alexiadis M, Jobling T, McNeilage J: Seladin-1/DHCR24 expression in normal ovary, ovarian epithelial and granulosa tumours. Clinical Endocrinology 2005, 63:111-115.

16. Doherty SC, McKeown SR, Lopez JA, Walsh IK, McKelvey-Martin VJ: Gene expression in normal urothelium depends on location within the bladder: a possible link to bladder carcinogenesis. European Urology 2006, 50:290-301.

17. Nagai MA, Ros N, Bessa SA, Mourão Neto M, Miracca EC, Brentani MM: Differentially expressed genes and estrogen receptor status in breast cancer. International Journal of Oncology 2003, 23:1425-1430.

18. Di Stasi D, Vallacchi V, Campi V, Ranzani T, Daniotti M, Chiodini E, Fiorentini S, Greeve I, Prinetti A, Rivoltini L, Pierotti MA, Rodolfo M: DHCR24 gene expression is upregulated in melanoma metastases and associated to resistance to oxidative stress-induced apoptosis. International Journal of Cancer 2005, 115:224-230

19. Luciani P, Gelmini S, Ferrante E, Lania A, Benvenuti S, Baglioni S, Mantovani G, Cellai I, Ammannati F, Spada A, Serio M, Peri A: Expression of the antiapoptotic gene seladin-1 and octreotide-induced apoptosis in growth hormone-secreting and nonfunctioning pituitary adenomas. Journal of Clinical Endocrinology \& Metabolism 2005, 90:6156-6161.

20. Luciani P, Ferruzzi P, Arnaldi G, Crescioli C, Benvenuti S, Nesi G, Valeri A, Greve I, Serio M, Mannelli M, Peri A: Expression of the novel adrenocorticotropin-responsive gene Selective Alzheimer's Desease Indicator-1 in the normal adrenal cortex and in adrenal adenomas and carcinomas. Journal of Clinical Endocrinology \& Metabolism 2004, 89:1332-1339.

21. Sarkar D, Imai T, Kambe F, Shibata A, Ohmori S, Siddiq A, Hayasaka S, Funahashi $\mathrm{H}$, Seo H: The human homolog of Diminuto/Dwarf1 gene (hDiminuto): a novel ACTH-responsive gene overexpressed in benign cortisol-producing adrenocortical adenomas. Journal of Clinical Endocrinology \& Metabolism 2001, 86:5130-5137. 
22. Lu X, Kambe F, Cao X, Kozaki Y, Kaji T, Ishii T, Seo H: DHCR24 is a hydrogen peroxide scavenger, protecting cells from oxidative-stress-induced apoptosis. Endocrinology 2008, 149:3267-3273.

23. Battista MC, Roberge C, Otis M, Gallo-Payet N: Seladin-1 expression in rat adrenal gland: effect of adrenocorticotropic hormone treatment. Journal of Endocrinology 2007, 192:53-66.

24. Friedrich MG, Weisenberger DJ, Cheng JC, Chandrasoma S, Siegmund KD, Gonzalgo ML, Toma MI, Huland H, Yoo C, Tsai YC, Nichols PW, Bochner BH, Jones PA, Liang G: Detection of methylated apoptosis-associated genes in urine sediments of bladder cancer patients. Clinical Cancer Research 2004, 10:7457-7465.

25. Kuehnle K, Crameri A, Kälin RE, Luciani P, Benvenuti S, Peri A, Ratti F, Rodolfo M, Kulic L, Heppner FL, Nitsch RM, Mohajeri MH: Prosurvival effect of DHCR24/Seladin-1 in acute and chronic responses to oxidative stress. Molecular and Cellular Biology 2008, 28:539-550.

26. Gao Z-H, Suppola S, Liu J, Heikkila P, Janne J, Voutilanen R: Association of $\mathrm{H} 19$ promoter methylation with the expression of $\mathrm{H} 19$ and IGF-II genes in adrenocortical tumors. Journal of Clinical Endocrinology \& Metabolism 2002, 87:1170-1176

27. Liu J, Li X-D, Vaheri A, Voutilainen R: DNA methylation affects cell proliferation, cortisol secretion and steroidogenic gene expression in human adrenocorticaol $\mathrm{NCl}-\mathrm{H} 295 \mathrm{R}$ cells. Journal of Molecular Endocrinology 2004, 33:651-662.

Pre-publication history

The pre-publication history for this paper can be accessed here: http//www biomedcentral com/1471-2407/10/201/prepub

doi: $10.1186 / 1471-2407-10-201$

Cite this article as: Simi et al., Seladin-1 expression is regulated by promoter methylation in adrenal cancer BMC Cancer 2010, 10:201

Submit your next manuscript to BioMed Central and take full advantage of:

- Convenient online submission

- Thorough peer review

- No space constraints or color figure charges

- Immediate publication on acceptance

- Inclusion in PubMed, CAS, Scopus and Google Scholar

- Research which is freely available for redistribution

Submit your manuscript at www.biomedcentral.com/submit
C Biomed Central 